\title{
The disappearance of Lake Chad: history of a myth
}

\author{
Géraud Magrin $^{1}$ \\ Université Paris 1 Panthéon-Sorbonne, France
}

\begin{abstract}
The article explores the hydropolitics of Lake Chad. Scientific and popular views on the fate of Lake Chad differ widely. The supposed 'disappearance' of the Lake through water abstraction and climate change is a popular myth that endures because it serves a large set of heterogeneous interests, including those supporting inter-basin water transfers. Meanwhile scientific investigations show substantial and continuing Lake level fluctuations over time, and do not support its projected disappearance. The task is to understand how the myth of the disappearing Lake has been engendered and used, by studying the discourses and the strategies of the main stakeholders involved. The Lake has been protected so far from massive water abstraction, and inter-basin transfer projects, due to the fragmentation of its political management, new security threats, and the piecemeal nature of the interests in play.
\end{abstract}

Key words: Lake Chad; environmental myths; hydropolitics; political ecology; inter-basin transfers

\section{Résumé}

Cet article aborde le lac Tchad d'un point de vue hydropolitique. Les discours scientifique et du grand public sur l'état du lac Tchad diffèrent largement. La « disparition » supposée du lac sous l'effet des prélèvements anthropiques pour l'irrigation et du changement climatique est un mythe qui perdure car il sert un ensemble d'intérêts hétérogènes, dont ceux favorables à un projet de transfert d'eau inter-bassins. Or les recherches scientifiques montrent que le lac a toujours fluctué au cours du temps, et que les dynamiques récentes ne conduisent pas à sa disparition, si souvent annoncée. Il s'agit ici de comprendre comment le mythe de la disparition du lac a été engendré et utilisé, en étudiant les discours et les stratégies des principaux acteurs impliqués. Jusqu'à présent, le lac a été protégé aussi bien de prélèvements massifs que d’un transfert interbassin par la fragmentation de sa gestion politique et par l'émergence de nouvelles menaces sécuritaires dans le bassin.

Mots clés: Lac Tchad; mythes environnementaux; hydropolitique; écologie politique; transferts entre bassins

\section{Resumen}

El artículo explora las hidropolíticas del lago Chad. Los puntos de vista científicos y de populares sobre el estado del lago Chad difieren ampliamente. La supuesta "desaparición" del lago debido a la captación de agua y al cambio climático es un mito popular que perdura porque sirve un conjunto amplio de intereses heterogéneos, incluyendo aquellos que están apoyando proyectos de transvases intercuencas de agua. Mientras tanto, las investigaciones científicas muestran fuertes y continuas fluctuaciones del nivel del lago a través del tiempo, y no son compatibles con su desaparición proyectada. El trabajo (el objetivo) es entender cómo el mito de la desaparición del Lago se ha generado y se ha utilizado, a través del estudio de los discursos y de las estrategias de los principales actores involucrados. El lago ha sido protegido hasta el momento de la captación masiva de agua y de los proyectos de transvases intercuencas, debido a la fragmentación de su gestión política, a las nuevas amenazas sobre la seguridad, y al carácter fragmentario de los intereses en juego.

Palabras clave: lago Chad; mitos medioambientales; hidropolítica; ecología política; los transvases intercuencas

\footnotetext{
${ }^{1}$ Professor Géraud Magrin, Université Paris 1 Panthéon-Sorbonne, UMR Prodig / UFR 08 - Géographie, 2 rue valette, 75 005 Paris, France. Email: Geraud.Magrin "at" univ-paris1.fr. I thank Jacques Lemoalle for his constant openness to sharing his thinking on Lake Chad, and particularly for his support in proofreading this article. Thanks to two reviewers and the Journal editors.
} 


\section{Introduction}

During the COP 21 Global Change summit held in Paris in December 2015, Lake Chad was on the agenda three times. During a mini African Summit held on the first of December with French President François Hollande and twelve African Heads of State, Lake Chad was discussed in relation to renewable energy, the future of the Niger River, and the Great Green Wall Project. Ms Nkosazana Dlamini-Zuma, head of the African Union Commission, stated that Lake Chad has shrunk from a surface area of 25,000 $\mathrm{km}^{2}$ in the 1960s to only 2,500 $\mathrm{km}^{2}$ today. Mahamadou Issoufou, President of Niger, underlined the close link between the drying up of Lake Chad and terrorism in an area threatened by the Boko Haram Islamist group since 2009. Idriss Deby from Chad called for an emergency international response for funding a water transfer mega-project in order to save Lake Chad.

The next day, some major international donors (notably the African Development Bank and the World Bank) organized a presentation of the Lake Chad Development and Climate Resilience Action Plan, prepared on behalf of the Lake Chad Basin Commission (LCBC). The plan is an ambitious, large scale development project aiming at strengthening the natural and human potential and resilience to hydrological variability of the Basin and its population, by funding road construction, providing public services (water, education, health) and supporting the agricultural sector.

On December 10th, the French Research Institute for Development (IRD) organized a side event, Act for Lake Chad, with civil society organisations from the Basin and researchers who had coordinated recent scientific popularization about the Lake (Lemoalle and Magrin 2014, Magrin et al. 2015). The French Minister of Environment, Ségolène Royal ${ }^{2}$, intervened during the closing session to say "...researchers of IRD should stop saying that Lake Chad is not disappearing. I will tell the researchers of IRD to stop saying that Lake Chad is not disappearing." In this article, I would like to enlighten the rationale behind these opposing narratives.

Lake Chad is an African geosymbol in a class of its own. After long arousing the curiosity of Arabian or European geographers and explorers, dreaming of finding the sources of the Nile there (Bouquet 2012, Krings and Platte 2004), it is apparently destined to disappear. From international conferences to media reports, a myth has grown up about its disappearance and the disastrous human consequences, but against all scientific evidence - scientists consider the fluctuating lake levels to be the result of an on-going process (Figure 1), and that the environmental conditions over the last four decades have been rather favourable for the populations living on its islands and shores. The claimed reasons for the announced disappearance are anthropogenic, directly by abstracting water for irrigation, and indirectly as the visible effects of global warming. The consequences of this disappearance would, of course, justify promising investments, heralding a return to the 1960 s golden age of development.

The issue here is to investigate the dual process whereby the resources of this great Sahelian lake (water, biodiversity, and agriculture in a broad sense) are portrayed in terms of scarcity, and how, in return, this is being exploited to drum up international funds that potentially carry risks. I shall test the hypothesis that the myth of the disappearing Lake Chad works because it serves a large set of heterogeneous interests, but that the Lake has been protected so far due to the fragmentation of its political management and the piecemeal nature of the interests in play.

This article is the outcome of a two-stage thought process. The first corresponds to the critical stance of French geography regarding environmental discourses (Brunel and Pitte 2010, Pelletier 1993, Rossi 2000, Veyret and Arnould 2008): a contradiction between the highly alarmist discourse of the disappearing Lake and my own knowledge leads me to challenge the former, which err on the side of oversimplification or pessimism (Magrin 2007). Secondly, a wish to understand how such stances operate lead me to mix hydropolitics (geopolitics applied to large hydraulic systems - see Raison and Magrin 2009) and a political ecology perspective (Benjaminsen 2012, Benjaminsen and Svarstad 2009, Gautier and Benjaminsen 2012, Peet et al. 2011). The latter takes an interest in the political stakes of discourses and practices established in

\footnotetext{
${ }^{2}$ Royal was a candidate for the French Presidential election of 2012 for the Socialist Party, and went to the second round; she lost against N. Sarkozy.
} 
the name of the environment. My approach echoes studies on the use of scientific errors in desertification and erosion management (see for example Batterbury and Warren 1999, Fairhead and Leach 1998, Tiffen et al. 1994) or in the climate change adaptation debate (Batterbury and Mortimore 2013). The task is to understand how the myth of the disappearing lake has been engendered and used, by studying the discourses and strategies of the main stakeholders involved.

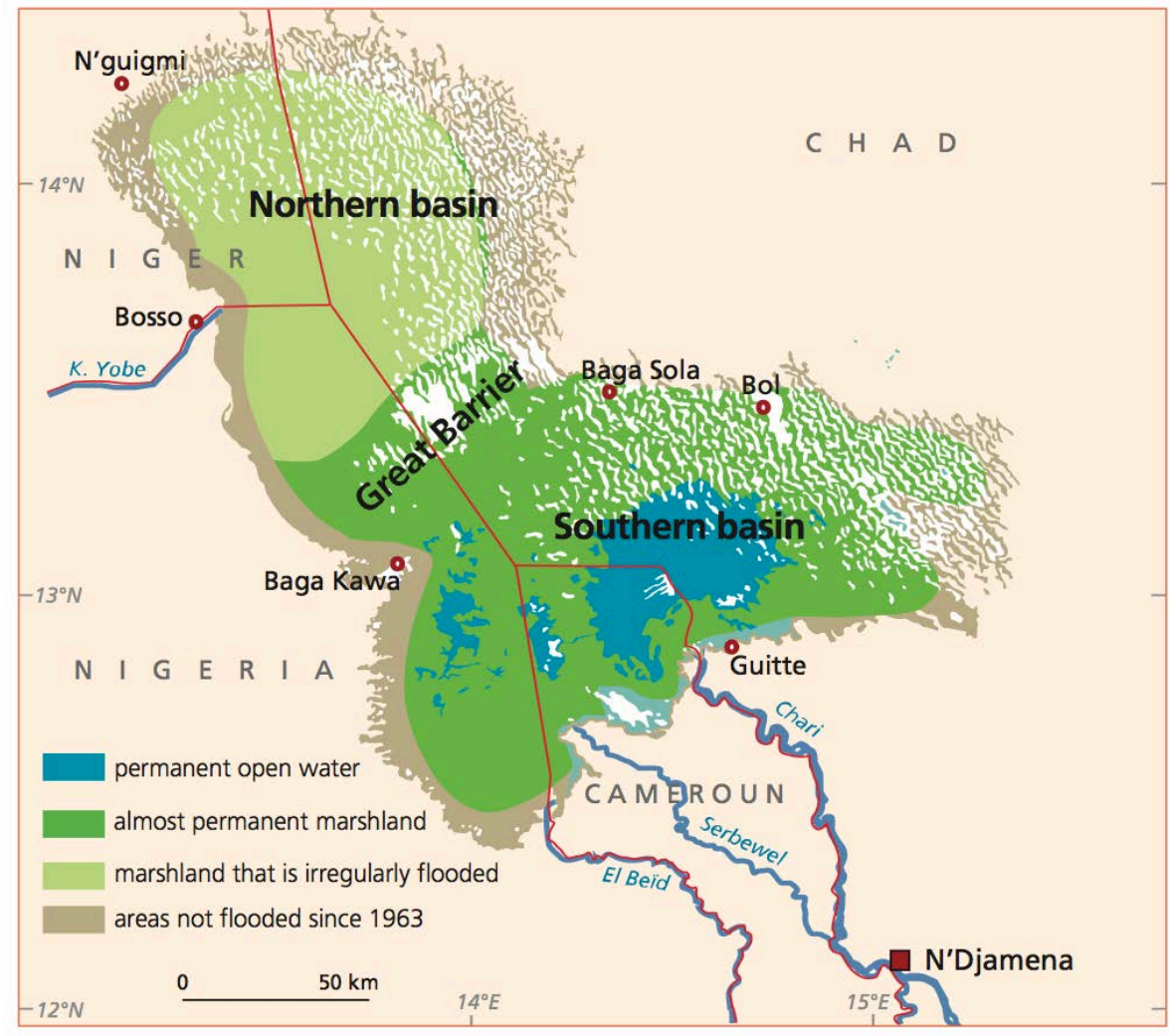

Figure 1: Schematic map of Lake Chad's average status in 2010. Source: Lemoalle 2015.

The analysis is based on two sources of information: firstly, science offering an understanding of the lake's situation - hydrology research by teams from the Institut de Recherche pour le Développement (IRD) on how the lake functions and evolves (Bader et al. 2011; Lemoalle 2003; Lemoalle et al. 2011, 2012; Olivry et al. 1996), along with my own work focusing on the livelihood system of the Chadian southern lake shores (Magrin 1996; Magrin et al. 2010). Secondly, some more piecemeal research collected from on-going participant observation (2010-2015) which led me to be associated with the scientific committee of the World Sustainable Development Forum Saving Lake Chad in N'Djamena (29th-31st October 2010), then cochairing a collective assessment for the LCBC (2012-2014) ${ }^{3}$, and finally co-authoring the World Bank and LCBC Lake Chad Development and Climate Resilience Action Plan presented during the COP 21.

I begin by placing the discourses on the disappearance of Lake Chad and its consequences for society in perspective, compared with available scientific knowledge. Then, I analyse how the myth operates and the

\footnotetext{
${ }^{3}$ An appraisal undertaken by IRD through a multidisciplinary panel of scientific experts designed to produce legitimate knowledge likely to help in decision-making on sensitive subjects. The collective appraisal of Lake Chad was chaired by Jacques Lemoalle (see Lemoalle and Magrin 2014).
} 
stakes underlying it. Lastly, I examine the interests of some key stakeholders championing the 'cause' of Lake Chad.

\section{On the 'disappearance' of Lake Chad and its consequences}

The theory of a disappearing Lake Chad, with disastrous human consequences, reigns as a dominant viewpoint. Yet, the scientific analyses paint a very different and converging picture of the Lake's situation.

\section{Disappearance?}

The long-held fear of the pending disappearance of Lake Chad resurfaced a few years ago and is now bordering on belief. At the turn of the $20^{\text {th }}$ century, the dread of seeing Lake Chad disappear figured in scientific publications. It was feared that the Lake would dry up over the long term (Tilho 1928), the main reason being the possible capture of the River Logone by the Benué (in the Niger basin), based on observations of a major water flow from the Logone floodplain (Chad basin) to the Benue-Niger basin at Éré (Cabot, 1964 1967, Dresch 1947). With the droughts of the 1970s and 1980s, the phantom of disappearance reappeared, although for a different reason (Pouyaud and Colombani 1989). In 1989, an abortive project to transfer water from the Ubangui promised to save the threatened Lake (Bonifica 1991). A decade later, an article appeared in the very scholarly Journal of Geophysical Research (JGR) announcing the pending disappearance of Lake Chad due to the drop in rainfall and human abstraction for irrigation (Coe and Foley 2001). It served as the basis for all the analyses corroborating the idea of the imminent Lake disappearance. The message was spread by publications and the website of NASA (National Aeronautics and Space Administration), notably via a set of maps derived from satellite images, which became an icon for the peddlers of the myth: it was claimed that the reduction in water area was inevitable and that the Lake would shrink regularly, and unrelentingly (Figure 2).
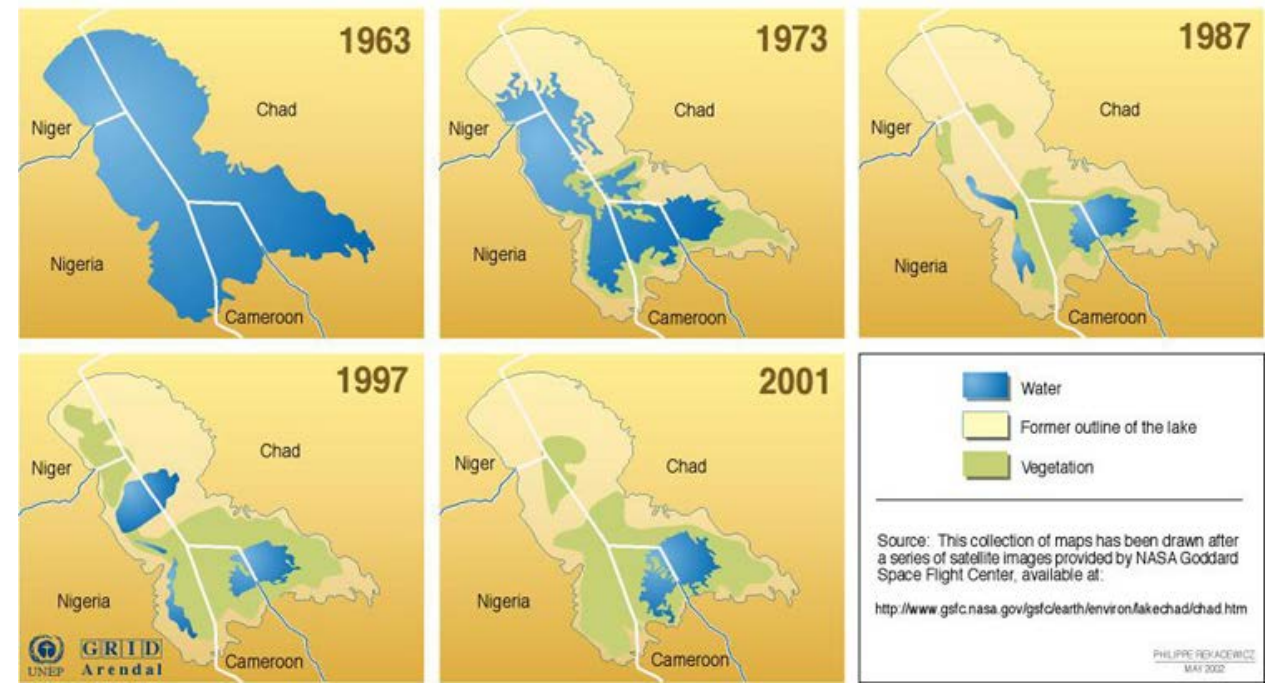

Figure 2: An icon, Lake Chad as seen by NASA (2001).

At the beginning of the 2000s, several media outlets mirrored this concern, notably in France. ${ }^{4}$ Then, like an old chestnut, the disappearance theory returned with force at the end of the last decade (2009-2012) (see Box 1). This FAO alert voiced the most frequent arguments: but the base figure $\left(25,000 \mathrm{~km}^{2}\right.$ of open water) and the 'current' figure $\left(1,500 \mathrm{~km}^{2}\right)$ in fact refer to the maximum reached in the $20^{\text {th }}$ century, in 1963 ,

\footnotetext{
${ }^{4}$ See Magrin 2007.
} 
and to the minimum open water area observed in the dry years, in 1973 and 1985. In March 2013, after a strong rise in water levels, 14,800 km² were flooded (Don-Donné Goudoum and Lemoalle 2014, Lemoalle and Magrin 2014).

\section{A humanitarian disaster is threatening the Lake Chad region due to shrinking water resources (...). \\ Due to climatic variability, climate change and population pressure (...) the lake has shrunk by 90 percent, from 25,000 square kilometres in 1963 to less than 1,500 square kilometres in 2001. \\ If water continues to recede at the current rate, Lake Chad could disappear in about twenty years from now, according to NASA climate forecasts.}

Box 1: The FAO concerned about the disappearance of Lake Chad. Source: FAO, Rome, 15th October 2009.

The situation of Lake Chad in 2014 was distant from the dominant diagnosis. The geography of the Lake explains its substantial variability, over multiple time scales:

- the Lake is located on the $13^{\text {th }}$ parallel and is therefore exposed to strong evaporation

- it is located in one of the very flat shallow depressions of the endorheic Chad basin ${ }^{5}$

- any change in the water balance (inflow/losses) leads to major variations in surface area.

In the recent Quaternary (6,000 BP), a mega-Lake Chad $160 \mathrm{~m}$ in depth occupied an area of $340,000 \mathrm{~km}^{2}$ (Leblanc et al. 2006). In recent centuries, Lake Chad has seen some major variations, drying up totally at the beginning of the $16^{\text {th }}$ century for a few years (Maley 1981). Prior to World War I, Tilho (1928) observed three levels: a Great Lake Chad of $25,000 \mathrm{~km}^{2}$ of open water, at an altitude of $284 \mathrm{~m}$ (asl), a Medium Lake Chad of 15-20,000 $\mathrm{km}^{2}$ of open water, with some 2,000 islands, and a Small Lake Chad with two separated pools and a water level below $280 \mathrm{~m}$, corresponding to the situation at the beginning of the $20^{\text {th }}$ century. The Small Lake has prevailed again since 1973 with open waters surrounded by a broad belt of swamplands. Its inundated area has varied around an average of $10,000 \mathrm{~km}^{2}\left(+-4,000 \mathrm{~km}^{2}\right)$ over the last fifteen years. A dry Small Lake Chad was seen on four occasions in the 1980s when an insufficient water input prevented any flooding of the northern pool, which remained completely dry for more than a year (Lemoalle 2015).

The key replenishment factor is the contribution of the Chari-Logone flood, which is reflected in the volume of rainwater in the Lake's basin. Lake-level fluctuations can therefore be considered on multiple timescales: annual (flood/recession), from year to year, depending on wet and dry phases (over a few decades), to longer periods (century, millennium). Thus, the current Lake is a Small Lake Chad, as often seen in the past. There has been no notable change in size since 1974, apart from annual drying and wetting. The Lake is formed by two pools (northern and southern pools) with substantial vegetation cover. The open waters are surrounded by swamp that is part of the reality of the Lake: beneath the vegetation, water and aquatic life are present, but are not emphasised on the NASA maps (Figure 2). NASA shows these in yellow

\footnotetext{
${ }^{5}$ The lowest point of the basin is the Bodélé depression.
} 
or ochre shades, more evocative of desert sands than a biologically active wetland. The focus on open water, which is easily identifiable on satellite images and corresponds more to the Western idea of a lake, and the failure to take swamplands into account, also explains the considerable differences in lake area estimates (Lemoalle and Magrin 2014). Interannual water level variations in the southern pool, which is directly fed by the Chari, are slight. In the northern pool, separated by the Great Barrier from the southern pool, there is a greater risk of drying-up. The northern pool has dried up totally on several occasions (twelve times between 1975 and 1994). But this did not occur between 1995 and 2013 (Lemoalle 2015). Water withdrawals for irrigation have little effect, amounting to 2 to 3 billion $\mathrm{m}^{3} / \mathrm{y}$ compared with the 25 to 30 billion $\mathrm{m}^{3} / \mathrm{y}$ of average inflow in recent years (Lemoalle et al. 2012). As for the effects of global warming on Lake Chad, scientists agree: if an increase in temperature is certain, the future rainfall over the basin cannot be predicted. The available climate models of the IPCC (April 2014) are too divergent to enable any reliable prediction of changes in rainfall in the central Sudano- Sahelian region that includes Lake Chad. Nonetheless, an increase in water inflow seems more likely than the opposite according to the majority of models (Roehrig et al. 2013).

Yet, the lake occupies a prominent position in climate change mythologies. One such example is the film The Inconvenient Truth (2006), by Davis Guggenheim, devoted to former American Vice-President Al Gore's action on climate change. The very short sequence of the film dedicated to African situations focuses on the central Sahel. After making allusion to the tragedies in Darfur and Niger (?!) caused by the droughts, Al Gore rapidly evokes the drying up of Lake Chad (saying it has shrunk from a big lake in 1963 to almost nothing today), adding to the numerous problems faced by neighbouring countries.

\section{Disaster?}

Inaccuracies are just as blatant when describing the human consequences of Lake Chad's so-called regressive dynamics. A few examples are quoted in Box 2. Historically, the Lake population was low, but there has been a substantial demographic growth in recent times. However, the figures commonly quoted systematically combine the population of the Lake and its shores with that of the Chad basin as a whole. ${ }^{6}$ In addition, the idea that the low water level of the current Small Lake Chad is detrimental to human activities needs to be qualified.

The islands of the Lake were a place of refuge for people in the ancient past (named Buduma in general but called Yedina in the north west of the Lake and Kuri in its eastern pool), but their origins are unknown (Baroin 2004, Urvoy 1949). Their belligerence prevented any major settlement on the southern shores up to the end of the $19^{\text {th }}$ century (Bouquet 1990). The Lake has exerted a strong attraction since the 1950s: firstly, for fisherfolk from the Chad basin and beyond (as far as Mali) (Krings 2004). On the southern shores in particular, the return to a Small Lake Chad freed up large areas of fertile sediment suitable for flood-recession crops and pasturelands (Magrin 1996, Réounodji 1995, Sarch and Birkett 2000). These resources attracted migrants driven from their Sahelian territories by droughts or by the Chadian conflicts of the 1970s-1980s. The lakeside population has risen from 700,000 people in 1980 (Bouquet 1990) to over 2 million in 2014. The 35 million inhabitants mentioned in the cited documents correspond to an extrapolation of the population of the entire basin undertaken in 1990 to the year 2000 (Kindler et al. 1990). In 2013, this basin had around 47 million inhabitants. But it is home to only 13 million inhabitants within a radius of 300 $\mathrm{km}$ centered on the Lake, including the major cities of N'Djamena and Maiduguri (around 1 million inhabitants each), for which Lake Chad has a significant influence on food availability and employment (Ngaressem et al. 2014).

The current Small Lake Chad affects places and activities differently. Fisherfolk complain about a decrease in yields. Undoubtedly, the shrinkage of the lake reduced fishery productivity for some time, since it is proportional to the flooded area (Wellcome 1979) - and there was a fishing crisis in the 1980s. However, in the following decade, with new techniques and a return to more favourable rainfall, productive fishing resumed (Krings 2004). Apparently, fishermen are increasing in numbers and the para-fiscal levies imposed

\footnotetext{
${ }^{6}$ The active drainage basin amounts to around one million $\mathrm{km}^{2}$.
} 
on the supply chain (by traditional chiefs, Water and Forestry staff, customs officers) suggest adequate production values.

\section{0 million people under threat}

Some 30 million people live in the Lake Chad region. They are suffering enormously from the drying-up of the lake and the deterioration of the agricultural production capacity of its basin. All the socio-economic activities are affected and overuse of water and land resources is also a major cause of migration and conflicts.

\section{Urgent action}

The humanitarian disaster that could follow the ecological catastrophe needs urgent interventions. The tragic disappearance of Lake Chad has to be stopped and the livelihoods of millions of people living in this vast area should be safeguarded.

FAO, Rome, 15 October 2009

In fifty years, the surface area of Lake Chad has been divided by ten. The very existence of four million Chadians, Cameroonians, Nigerians and Nigeriens who live on its shores is under threat

Ouest France, 4 January 2009

Today, Lake Chad is nothing more than a small lake around which $\underline{30 \text { million }}$ climate refugees are teeming

Actualité internationale, April-May 2010

Box 2: Consequence of the disappearance of the Lake.

Irrigated agriculture also suffered from the return to Small Lake Chad, with certain large agricultural land developments, especially in Nigeria, seeing their profitability jeopardized by extra costs due to pumping over greater distances. However, the drop in water level was not the only reason for this crisis (Bertoncin and Pase, 2012, Magrin 2009). At the same time, there was a remarkable boom in recession crops. In the northern pool, market gardening took over from fishing in dry years (Luxereau et al. 2011). On the southern shores, successive efficient cropping innovations led to a boom in farming systems connected to the urban markets of Maiduguri and N'Djamena. They produce maize and vegetables in particular, and with limited public assistance (Magrin 1996, Magrin et al. 2010, Mbagogo and Magrin 2015, Raimond et al. 2014, Réounodji 1995). The extension of flood-recession pastures is also contributing to a boom in sedentary livestock herding among lakeside dwellers, and is helping to secure the livelihood of pastoral groups (Peuls, Arabs, Toubous). Form the 1970s to the 2000s conflicts between farmers and herders have remained limited, even along the more densely populated southern banks.

Thus, since the 1990s, the Small Lake Chad configuration has offered "good land" in the heart of the Sahel, as reflected in the positive migratory balance, far removed from disaster imagery (Ngaressem et al. 2014). Any 'climate refugees', if they exist, come to the Lake to find resources they lack elsewhere. However, the balance is fragile: the northern pool remains vulnerable; resources, especially land, are tending towards saturation, the relations between groups rely on local political negotiation, and it is unsure that the lands and waters of the Lake are able to cope with the expected doubling of the population in the next twenty years. The context of insecurity related to the surge in support for the Boko Haram Islamic extremist group has 
exposed prevailing socio-political tensions, shown locally between autochtonous Yedina and incoming Hausa migrants.

\section{Effectiveness and limitations of an eco-political myth}

Now we need to understand how this myth of the pending disappearance of Lake Chad has operated, by whom and why it has been exploited, and how successful the portrayal of scarcity has been in drumming up international financial resources.

\section{A secondary and intermittent international 'cause'}

The mobilization of support for Lake Chad waxes and wanes in line with the international and political agenda, with the windows of visibility offered to this global but rather marginal topic by international news media, and the messages from scientists that find the arguments in favour of 'saving Lake Chad' to be ambiguous. At the end of the 2000s, Lake Chad became an international cause, suited to a context of seeking atonement and compensatory approaches for global warming (Benjaminsen 2012). The cause was a mixture of Western guilty conscience, sensationalism in the media (to interest the public in an environmental issue in Africa, a minimum of damage was required ${ }^{8}$ ), and through a "snowball" effect: if all colleagues are interested in such a topic, then something must be happening, a "mythology manufacturing" mechanism in an era of mass information (Bronner 2013). But the interest it aroused was intermittent, overshadowed by each major event in the international news (tsunami in Asia, earthquake in Haiti, seismic activity and nuclear accident in Japan, French and American elections, war and security threats in Mali, etc.).

The subject of Lake Chad came up at major international conferences on the environment, stressing the idea that it was in a critical situation and that something had to be done to save it: World Water Week in Stockholm, and the Copenhagen summit (2009), the Cancun summit on global warming (NovemberDecember 2010), the Nagoya summit on biodiversity (October 2010), a Francophonie summit in Montreux (October 2010), the France-Africa summit in Nice (May 2010) and others. It was also a major topic at the World Water Summit in Marseille in 2012 and in Rio the same year. At the end of October 2010, the $8^{\text {th }}$ session of the World Forum on Sustainable Development (WFSD) in N'Djamena brought to Lake Chad's sickbed five African heads of state, a strong French and international media delegation (France 24, Nippon Hōsō Kyōkai (NHK), Radio France Internationale (RFI), la Chaîne Parlementaire française, La Croix, Ushuaïa Magazine, Jeune Afrique, etc.), and several hundred participants from Chad and the sub-region.

Scientific dysfunction has also played a role in this myth. The JGR article by Coe and Foley (2001) predicting the disappearance of the Lake was all the more influential in that it was relayed by articles published on the NASA website based on satellite images (such as Chandler 2001). However, the choice of these images is debatable, as the dates (month and year) were chosen in order to show the unrelenting shrinkage of the water body. ${ }^{9}$ Taking into account the seasonal and annual lake level variations, choosing different dates could have shown exactly the opposite! But articles posted on the NASA site were armed with the authority afforded to it by its achievements in space, and the aura of US scientific expertise, which strengthened their message. Coe and Foley backed most of the discourses championing the Lake's disappearance and were quoted everywhere.

And yet, the arguments were based on a mistaken diagnosis, arising from a double error committed by the authors. Firstly, a loss of 2.5 billion $\mathrm{m}^{3}$ of water in the analysis, arising from a poor understanding of an

\footnotetext{
${ }^{7}$ The enlistment of numerous young Yedina islanders in the Boko Haram groups could be a means for them to get rid of the Hausa immigrants, threatening their control over land and fishing grounds (oral communication by Christian Seignobos, IRD).

${ }^{8}$ When preparing the WFSD (October 2010), I was interviewed by a journalist from Japanese television (NHK). I explained to her at length how I saw the the Lake's situation. At the time of filming, she nonetheless asked me to explain to what degree the current shrinkage was a disaster. Otherwise, why would her editors have sent her? A few weeks later, on the shores of the Lake, the journalists who had come to take pictures of an African Aral Sea were faced with fishermen complaining about severe floods. Their confusion offered this researcher a sweet reward.

${ }^{9}$ The months are never indicated. Yet given the flood/recession regime of the Lake, this is essential information.
} 
article in French by Vuillaume (1981); secondly, and above all, a large over-estimation of irrigation withdrawal due to an erroneous personal communication received by the authors. In fact, irrigation was estimated by Coe and Foley to be using 11.5 billion $\mathrm{m}^{3}$ per year, i.e. around half the inflow into the Lake in a Small Lake Chad context, rather than 2-3 billion $\mathrm{m}^{3}$ in reality. On a trip to Montpellier shortly after publication, the authors are said to have acknowledged their errors, but neither their laboratory nor the journal considered it worth correcting them publicly. ${ }^{10}$

What remains surprising is that the widely dominant institutional and political discourse on Lake Chad relies on a single article - whose mistaken conclusions were not subsequently adopted or agreed by any further scientific analysis. Since then, a significant output has been produced by a number of authors (Bader, Favreau, Genthon, Lemoalle, Leduc) not necessarily working with the same perspective, and whose conclusions refute Coe and Foley's interpretations. This work has never been used by the media or specialized institutions. Just as surprising is the silence of NASA, which had the ability to qualify or rectify this doxa without any shadow of a doubt, many years after the article of 2001 that gave rise to it. But it refrains from doing so. And for good reason: a milder diagnosis would hardly supply material for spectacular 'headlines', or for requests for major funding.

\section{Projects to be legitimized}

The threat of the disappearance of Lake Chad was constructed by different stakeholders who were also driven by interest in drumming up international aid. At the end of the 1980s a plan, called Transaqua, was drawn up by the Italian Bonifica consulting office to transfer water from the Congo basin to tackle the identified risk of Lake Chad drying up (Bonifica 1991). The LCBC quickly latched onto the idea of transferring water to save the Lake. This involved enlarging the Commission to include the Central African Republic, which was done in 1994. The LCBC then assigned the country's president, Ange-Félix Patassé, to promote the project (CBLT 2011).

This project followed on from a long history of gargantuan water transfer proposals fulfilling similar functions: at the end of the $19^{\text {th }}$ century, Élie Roudaire developed a Saharan sea project based on the digging of large trenches to link some Tunisian and Algerian sebkhas located below sea level (Dubost 1998, Létolle and Bendjoudi 1997, Marçot 2003). In addition to fishing and transport, humidification of the surrounding climate was expected through evaporation. Later, Hermann Sörgel (1932) drew up a project for large navigable trans-African waterways.

Such projects form part of the fascination for large water-based developments in Africa, as analysed by Sautter (1987): their sheer scale gives them hydropolitical value, and the State can use their Promethean dimensions to legitimize itself by asserting its control over nature. In addition, such a project for Lake Chad gives the illusion of being able to solve all the problems of a vast area in one go, namely enabling navigation and transport, fishing on the Lake and major irrigation in the basin, and supplying hydroelectricity (CBLT 2012a). Without explicitly saying so, such arguments are based on the initial transfer scenarios provided by Transaqua, which envisaged successively transferring 100 billion $\mathrm{m}^{3} / \mathrm{y}$ from the Congo, then $40 \mathrm{billion}^{3} / \mathrm{y}$ from the Ubangui, under projects including extended navigability between the Congo, Chad and Niger basins.

These projects were interesting for the major donors, who found the opportunity to overcome the usual aid absorption problems of the least advanced countries. They also attracted the interest of many stakeholders - middlemen, consultants, various companies - by enabling the circulation of large sums of money across and under the table.

Apart from a tenuous scientific justification, its many uncertainties and high cost made water transfer projects difficult to justify (Magrin, 2011): the risks to biodiversity (e.g. the spread of the water hyacinth from the Congo basin to the Chad basin where it does not exist) and to the wetlands affected by the

\footnotetext{
${ }^{10}$ Discussions with Jacques Lemoalle.
} 
canalization of the Chari would not be negligible. Recent human settlements following the new banks of the Lake would be displaced. The winners and the losers would have to be weighed up, depending on the transfer options and economic choices to be specified.

The feasibility study undertaken by the CIMA consulting office for the LCBC recommended an option of transferring 3.4 billion $\mathrm{m}^{3}$ from a dam constructed at Bria on the Kotto river (CIMA International 2011a and 2011b). The LCBC finally chose a combined transfer of about 7 billion $\mathrm{m}^{3}$ from the two dams of Bria and Palambo (Figure 3). This transfer would not enable a reinstallation of 'Medium Lake Chad', and it would have limited effects on the southern pool (with little change to be expected for irrigated agriculture). But its main merits would be to secure the supply of water to the northern pool if some climate scenarios came to pass (Magrin et al. 2014), or at least to maintain the present equilibrium of Lake Chad despite a rise of upstream irrigation abstraction. One major problem was the cost of the project, estimated around US\$14 billion. Such an amount seemed out of all proportion when compared with public development aid - around US $\$ 150$ million per year in Chad in 2012 - or with the Chad-Cameroon petroleum project, which was presented in 2000 as the largest private investment in the history of sub-Saharan Africa (US\$3.7 billion) for a resource that was more profitable than water transfer.

It is not that easy to evaluate what the habitants of the Lake think of the transfer project. On the one hand, some people may not to wish to contradict the official discourse. Likewise, many livestock herders are favourable to water transfer because in their minds, a high Lake level is associated with good times (Rangé, 2016): less agricultural and cattle pressure on the pastures, and shorter stays on the banks of the Lake because the grass is abundant in the hinterland. These situations would apply in rainy years. But a medium Lake level due to a water transfer would not establish such favourable conditions if the rain doesn't increase in the Basin. On the other hand, some inhabitants of the islands and of the inner banks of the Lake, which settled there in the Small Lake context, are strongly opposed to a project that would oblige them to move.

In geopolitical terms, this project would mean establishing cooperation between the LCBC member states and those of CICOS (International Commission of Congo-Ubangui-Sangha). The structural difficulties of the latter, especially in CAR and the Democratic Republic of Congo, did not seem compatible with the security needed for such an investment. Lastly, this project, intends to increase the water supply without any clear vision of the uses to be made of it, appearing anachronistic at a time of integrated water resource management (IWRM) which favours management by demand rather than increases in supply (Blanchon 2011, 2013).

This said, the African context in the 2000-2014 period carried an aura of the 1960s, which seemed propitious to major hydraulic ambitions, following the structural adjustment period. There was a notable return of the temptation to ensure development through large infrastructure (Magrin 2010). Environmental rents were a novelty in the 2000s (Magrin 2013): they were intended to control the impacts of global warming in the poorest countries, the main victims of the pollution emitted by rich nations. Their forms were initially uncertain but are now established, but newly created mechanisms are subject to strong controversy (REDD mechanisms ${ }^{11}$, carbon credits). One critical element is that they primarily benefit those emerging countries that have the political-administrative ingenuity to capture them, and are of little benefit to the poorest countries, particularly in Africa (see Hansen et al. 2009). Could the nations of the Chad Basin benefit from the Green Economy?

\section{Heterogeneous interests and a hazy 'cause'}

Various stakeholders are involved in the Lake Chad disappearance myth, and the search for funding to save it. Such diversity explains the nature of the myth: resilient but intermittent and, so far, not very effective in drumming up financial resources.

\footnotetext{
${ }^{11}$ Reducing Emissions from Deforestation and Forest Degradation in Developing Countries.
} 


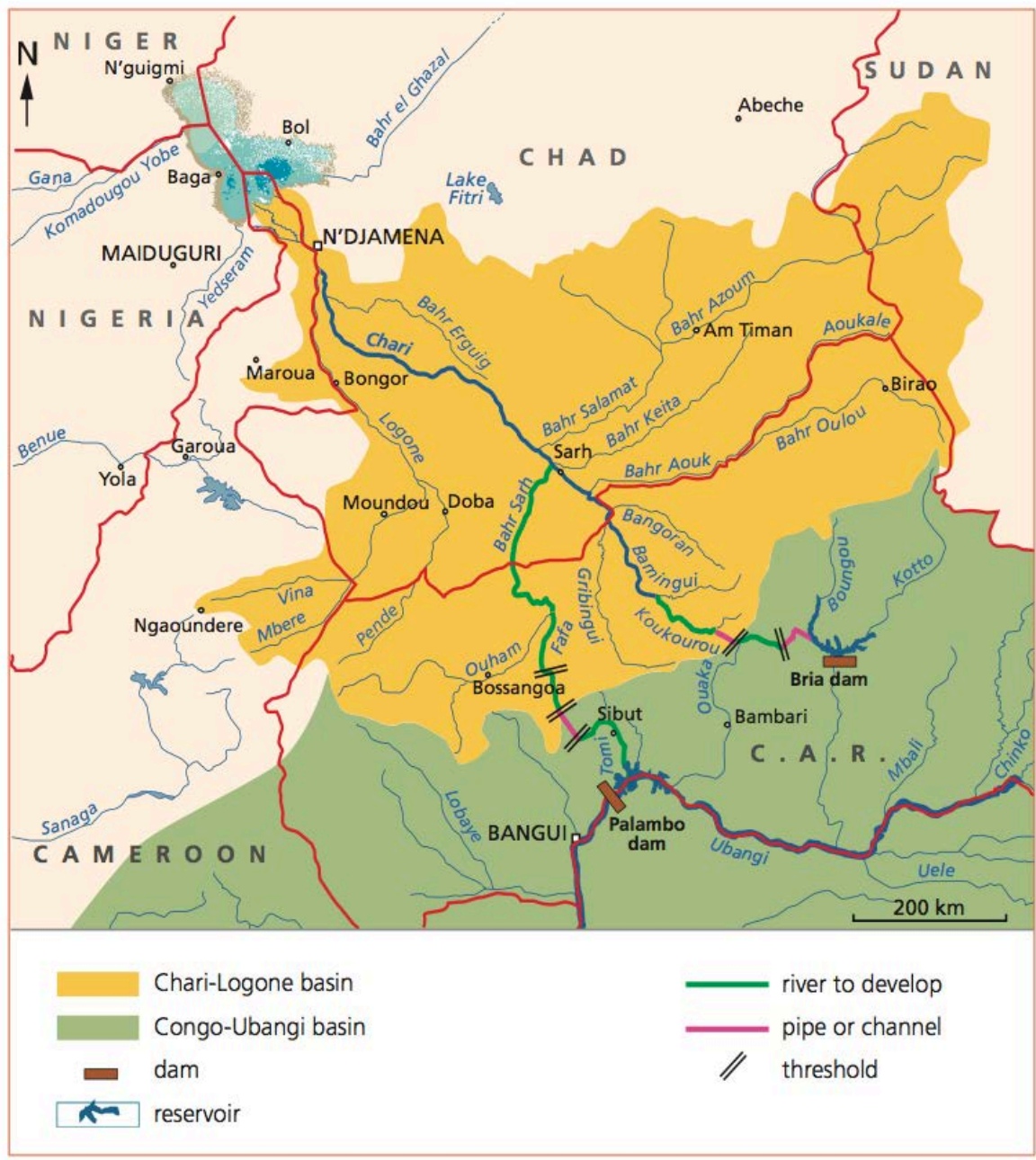

Figure 3: The water transfer options studied by LCBC (2009-2011). Source: Magrin and Lemoalle 2015.

\section{The LCBC, between political injunction and donor clout}

The LCBC occupies a central position in the debates about Lake Chad. It was set up in 1964, and is one of the oldest African regional institutions for basin management. It has a tumultuous past, like that of its member States. It was often paralysed by arrears in contributions (CBLT 2011) and by border conflicts between Nigeria and Cameroon in the 1990s, for which Lake Chad was one of the secondary theatres. ${ }^{12}$ It had irregular funding from a large number of projects and partnerships, and was obliged to undergo successive reforms.

The LCBC therefore faces a dual constraint: it has to manage the internal contradictions of States with indecisive strategies, with an erratic interest in the Lake, and with weak institutional capacities; it depends on fragmented international aid from a large number of donors. ${ }^{13}$ At a time of limited achievements, the interbasin transfer idea became a flagship project, which it hoped could be a driving force. Successive executive secretaries made it a central challenge for its legitimization and survival. However, to my mind, it did more harm than good to the institution (Magrin 2014), because it has yet to convince potential donors, thereby

\footnotetext{
${ }^{12}$ From 1987 to 2004, Nigeria occupied part of the Cameroonian lake zone around the island of Darak.

${ }^{13}$ A diagnosis undertaken for the European Union identifies almost 25 main partners in the basin (Ladel 2007).
} 
contributing more to a kind of institutional schizophrenia between political authorities reiterating at each summit their commitment to the transfer project (see CBLT 2011) and internal planning documents financed by international assistance (Global Environment Fund [GEF, European Union, etc.) which did not even mention the prospect of the transfer (CBLT 2008a and 2008b, 2012b).

At the end of its last reorganization (2009-2012), a strategic framework and an investment plan (20132017) were adopted, including almost sixty projects, but the round table of donors called for at the N'Djamena forum in October 2010 has been long in coming. In April 2014, the LCBC presented to a round table in Bologna a very ambitious investment plan of US\$800 million - ten times that of the last five-year plan - of which several components are to launch the transfer project. ${ }^{14}$ It was only partially funded, mainly by the African Development Bank (ADB).

\section{Differences of interests in the basin States}

The LCBC's difficulties also reflect the different influence of the member States in its bodies, and the importance of Lake Chad to these countries. Today, the LCBC has six member States. The four founding States share the shores of the Lake. However, for Niger and Cameroon, Lake Chad is a part of the world to which little thought had been given until very recently by those in the respective capitals, situated over $1,500 \mathrm{~km}$ away from its shores. Historically, Nigeria is the heavyweight of the LCBC: it alone provides over half its budget and designates the successive Executive Secretaries. For Nigeria, Lake Chad also has peripheral stakes. In the State of Bornu adjacent to Lake Chad, Boko Haram violence has given this region a new geopolitical interest since 2009. But this does not have any visible links to the Lake's water management challenges. The strategy of Nigeria regarding LCBC, as in how it deals with regional organizations in general, is difficult to interpret: it seems that its main objective is to keep control over the joint institution to ensure than nothing concrete takes place in them. ${ }^{15}$

The Lake is important to Chad: half its area is located in its territory. The area from Lake Chad to the Chari-Logone Mesopotamia is the demographic, economic and political heartland of the country, home to more than half its population. During the golden age of development (1950-1960), Lake Chad was a secondary, but significant, strategic development pole with the Bol polders and their irrigated wheat crops, destined to become the granary of the country (Bouquet 1990, Bertoncin and Pase 2012). But since the beginning of the 2000s, Chad has been in "petroleum mode" (Magrin 2013), and since the weapons fell silent in 2008 the country has returned to its developmentalist ambitions that remained latent because of the conflicts. It seems that President Idriss Déby discovered the environmental cause in $2007 .{ }^{16}$ For example, in 2009, the President signed a decree banning logging throughout the national territory to control desertification; on several occasions, he also stepped up controls over fishing gear use, particularly on the Lake. This turning of the screw was done in the - abrupt - manner favoured by the Chad State.

The interest of the Chad government for the Lake Chad cause shows consistency in this context, where political control, and internal and external legitimization strategies combine with a search for environmental rents. This recent period when Lake Chad attracted the media (2009-2012), occurred when the Chad President held the rotating presidency of LCBC.

The handover to President Issoufou of Niger, in 2012, was not accompanied by a withdrawal of the water transfer claim. Indeed, Niger would seem to be the main recipient of securing water for the northern pool. In addition, exploration of the Agadem oil deposits by the China National Petroleum Company is being carried out in the hinterland of Lake Chad (since 2009), integrating this area within the scope of national developmentalist ambitions. A major project would therefore strengthen both the control over this area and the social peace necessary for petroleum operations.

\footnotetext{
14 See the working documents of the Bologna round table, 26 March 2014, on the LCBC website: http://www.cblt.org/fr/documents-de-travail-de-la-table-ronde (consulted 7 April 2014).

${ }^{15}$ Discussion with a technical assistant at the Niger Basin Authority (NBA), Niamey, November 2011.

${ }^{16}$ Discussion with a Chadian senior civil servant, Paris, October 2010.
} 
On the southern edge of the basin, the CAR has been in favour of the transfer project from the outset. Apart from the construction of dams which could provide it with hydroelectricity, the project would, above all, offer the advantage of integrating this poor and marginalized country into the regional system of political and economic relations. However, one obstacle to the project lay in CAR. While the envisaged transfer of 7 billion $\mathrm{m}^{3} / \mathrm{y}$ was insignificant compared with the flow rate of the great Congo (1,000 billion $\mathrm{m}^{3}$ per year), its impacts (on navigation, hydroelectricity) have been questioned. But above all, what would be the interest of giving its waters to Lake Chad? And who would guarantee that the agreements would be respected, in a country with weak institutions?

Lastly, before being drawn into the hurricane of the Arab spring, Gadaffi's Libya entered the discussions on the future of Lake Chad. It defended the transfer project at the Earth Summit in Johannesburg in 2002. In October 2010, the WSDF devoted to Lake Chad provided Gadaffi with one of his last international tribunes. In the meantime, Libya had joined the LCBC as a member State in 2008 - the theoretical Lake Chad watershed was, on some maps ${ }^{17}$, encroaching a little on its territory. The Brotherly Leader and Guide of the Revolution certainly used Lake Chad as an emblem and inspiration for his panAfricanist ambitions. However, according to some authors, Libya apparently had more direct interest in the transfer project. ${ }^{18}$ Indeed, while the country was exploiting its Saharan fossil aquifers in an unsustainable manner, the possibility of their subterranean replenishment via a resupplied Lake Chad was being closely examined by some Libyan senior civil servants. For its part, Sudan was accepted as a member of the LCBC in 2000, on the condition that its Parliament ratify the agreement, which the quarrelsome context with Chad that prevailed between 2005 to 2009 has so far prevented.

\section{The role of France: from transfer to environmental rents}

France's contribution to the 'cause' of Lake Chad illustrates its capacity to influence, and its limits. France funded some of the Bol polders studies and projects in the 1950s-1960s, and greatly contributed to scientific knowledge of this aquatic system via the Office de la recherche scientifique et technique Outre-mer (ORSTOM). During the civil war in Chad from 1979 to 1982, ORSTOM left the country but its activity continued on a smaller scale, before regaining momentum in the 2000s. In recent years, France was not among the main Lake Chad donors, which include the African Development Bank, the European Union and German cooperation. On the other hand, France has strategic interests in Niger (uranium mines operated by Areva) and in Chad (with a permanent military presence since the wars against Libya in the 1980s which has been used in several regional conflicts). France could not pass over the Lake Chad 'cause', when it was presented as a priority by the same Chad authorities that it had lent military support to in the 2000s.

France's involvement in the Lake Chad debate is substantial but indirect. This is partly because of the role of Emile H. Malet, director and founder of the French language journal Passages and of the Adapes think tank, and organizer of the World Sustainable Development Forum - a series of conferences organized in France and Africa on various topics such as energy, the environment and international relations. PassagesAdapes is a small entity mainly relying on the dynamism, the charisma and the political network of its director. At the WSDF in Brazzaville (2008), E.H. Malet was asked by the Chadian Environment Minister to organize an event in N'Djamena in support of Lake Chad. He accepted, in a period of positive FrancoChadian relations - Paris had provided Idriss Déby with decisive support against Sudan-backed rebels in February 2008 and obtained in exchange the transfer to France of some protagonists of the Arche de Zoé affair. $^{19}$

\footnotetext{
17 On other maps, the theoretical drainage basin of Lake Chad encroaches very slightly upon Algeria, not Libya. Nowadays the hydrologically active basin is mainly located in the south of the Lake, with the exception of the Komadugu Yobe river basin, whose contribution to the Lake balance is very small.

${ }^{18}$ Discussions with a technical assistant at LCBC (2008), and with Jacques Lemoalle.

${ }^{19}$ During the Darfur conflict, a small French association was convicted of attempts to abduct children in the East of the country and its officials were hastily judged in Chad. Their fate poisoned Franco-Chadian relations for several months (2007-2008).
} 
The N'Djamena forum was mostly funded by Chad, but Passages and its many guests have been supported by Paris, which backed the initiative at the highest level. The forum was held from 29 to 31 October 2010, and was a success: organized in just a few months, bringing together 5 major heads of State (including MM. Gadaffi, Goodluck Jonathan from Nigeria, and Abdoulaye Wade from Senegal), several hundred participants, and many journalists. A great diversity of speakers took part in the forum (researchers from different countries, members of civil society, representatives from the Ministries of Environment or Water of the countries involved, etc.). They were too numerous for a focused debate to take shape. Nevertheless, the diversity of opinions was revealed, notably the opposition regarding the Lake's fate between scientists and those forecasting its disappearance with disastrous consequences. ${ }^{20}$ At the end of the forum, I. Déby (the serving chairman of the LCBC) named E.H. Malet as a roaming ambassador for Lake Chad responsible for promoting and following the recommendations of the forum. The key recommendations were to continue studies on the lake's behaviour and on the means to preserve it, and the classification of the lake as a UNESCO World Heritage site.

For Paris, it was a matter of exerting influence over this topic despite the tight budget context. In the higher French administration the Lake's disappearance theory did not hold credence and water transfer was seen as a passing fad. Nevertheless, it was necessary to accommodate not only the LCBC, but especially a self-assertive Chadian government which had just quarrelled with the World Bank over its petroleum project (Pegg 2009). France did not want to push Chad too far into the Chinese fold - with China developing petroleum operations in Chad since 2007, that were backed by multifaceted official cooperation with no strings attached (Magrin and Maoundonodji 2012).

In 2009, the LCBC used its own funds ${ }^{21}$ to launch a feasibility study for transferring water from the Ubangui to Lake Chad. The study was undertaken with great discretion and completed at the end of 2011. The CIMA study produced two documents bearing witness to the reticence of the authors and the probable intervention of the sponsor in the technical analysis. The draft final report dated December 2011 was noncommittal (CIMA International, 2011b: 49). Of the two transfer options considered, a first was not thought to be realistic due to the excessive difference in elevation to be overcome; a second was considered technically feasible but not recommended due to costs outweighing the expected benefits. The summary version of the study, dated November, but apparently completed prior to that (CBLT 2011a), seems to have been influenced by an official acceptance workshop organized at the beginning of 2012 (CBLT 2012a): it concluded that the transfer was technically feasible and recommended the option of a diversion from the Kotto river, combined with the construction of a dam at Palambo, with a view to ensuring project profitability through hydroelectricity generation. Finally, in 2014, LCBC chose a combined transfer from the two dams. This study may therefore have no impact on the paralysing tension in which the LCBC has been stuck since the 1990s, while providing a lifeline to the champions of the project, without convincing the sceptics.

In a context of strong regional instability around the Lake Chad Basin (in Darfur, South Libya, Borno Nigeria, the Central African Republic), France seeks to keep its political influence by maintaining good relations with different States, and particularly with Chad, which is a key ally and appears as a pole of political stability despite its authoritarianism. Thus, the purpose of French involvement in the Lake Chad issue is to lead the LCBC to give the impression of sufficient problems to justify international mobilization, while leaving aside the actual major water transfer engineering project.

After COP 21, the security issue in Africa has trumped long term water management for $\mathrm{AFD}^{22}$ and the World Bank. However, waiving what has been the rallying project in the region for twenty years, energetically defended by several heads of State, is no easy matter. The challenge is to initiate change among civil servants and politicians in the different countries. The shrinking of Lake Chad is not only a myth, it is also a jail.

\footnotetext{
${ }^{20}$ See the proceedings of this forum in issue No. 166 of the journal Passages.

${ }^{21} 5$ million dollars provided by Nigeria.

${ }^{22}$ Agence Française de Développement.
} 


\section{Conclusion}

An international Lake Chad campaign has been sketched out over the last few years, based on the long-held concern about the disappearance of this great lake of naturally variable surface area. The emphasis placed on depicting the depletion of natural resources is designed to incorporate new environmental rents intended to compensate for the effects of global warming. But it does not work very well: granted, Lake Chad has acquired the status of a global environmental icon, but it remains of secondary interest, condemned to exist only within narrow windows of spare media time.

If the myth is not an efficient one, it is because it is fragile. For good and bad reasons, just as COP 15, the Copenhagen climate change conference in 2009 was blown away by the squalls of a bitter winter, the myth of the disappearing lake was staged at a time coinciding with heavy annual rainfall. Yet the severe floods of 2010-2011 and 2012-2013 did not change hydrological uncertainty over the medium term. The problem with the Lake is one of complexity, after sustainable development models have been exhausted: how can fragile and limited natural resources be managed in a context of strong population growth, uncertainty surrounding the effects of climate change, limited national and regional governance, and insufficient and poorly coordinated aid? The degradation of the regional security situation because of Boko Haram gives an even more dramatic dimension to these issues. In this respect, Lake Chad needs to be seen more as a model of the challenges facing Sahelian Africa than for its exceptional lacustrine characteristics. Instead of topdown infrastructure projects, the challenge is involving the inhabitants in thinking through the future of the Lake. In order to do so, sharing accurate environmental and geographical information could be a first step in order to save it.

\section{References}

Bader J.-C., Lemoalle J. and M. Leblanc. 2011. Modèle hydrologique du Lac Tchad. Hydrological Sciences Journal 56(3): 411-425.

Batterbury, S.P.J. and A. Warren. 1999. Land use and land degradation in Southwestern Niger: change and continuity. Final Report to the ESRC Global Environmental Change Programme.

Batterbury, S.P.J. and M.J. Mortimore, 2013. Adapting to drought in the West African Sahel. In Palutikof, J. and D. Karoly (eds.). Natural disasters and adaptation to climate change. Cambridge: Cambridge University Press. Pp. 149-157.

Baroin, C. 2004. What do we know about the Buduma? A brief survey. In Baroin C., G. Seidensticker-Brikay and K. Tidjani (eds.). Man and the Lake. Proceedings of the $12^{\text {th }}$ Mega Chad Conference. Maiduguri: Center for Transaharan Studies. Pp. 199-217.

Benjaminsen T.A., 2012. Changements climatiques et conflits au Sahel. In Gautier D. and T.A. Benjaminsen (eds.). Environnement, discours et pouvoir. L'approche Political ecology. Paris: Quae. Pp. 181-199.

Benjaminsen T.A. et H. Svarstad. 2009. Qu'est-ce que la « Political ecology »? Natures Sciences Sociétés 17: 3-11.

Bertoncin M. et A. Pase. 2012. Autour du lac Tchad. Enjeux et conflits pour le contrôle de l'eau. Paris: L'Harmattan.

Blanchon D., 2011. Les transferts interbassins: l'expérience sud-africaine. Passages 166: 45-48. (special issue Sauver le lac Tchad).

Blanchon D. 2013. Atlas mondial de l'eau. Défendre et partager notre bien commun. Paris: Autrement.

Bonifica S.A. 1991. Transaqua: une idée pour le Sahel. Rome: Bonifica Italstat gruppo IRI.

Bouquet C. 1990. Insulaires et riverains du lac Tchad. 2 vols. Paris: L'Harmattan.

Bouquet C., 2012. Le spectre de la géographie physique plane sur le lac Tchad. Dynamiques environnementales 29: 17-26.

Bronner G. 2013. La démocratie des crédules. Paris: PUF. 
Brunel S. and J.R. Pitte (eds.). 2010. Le ciel ne va pas nous tomber sur la tête. 15 grands scientifiques géographes nous rassurent sur notre avenir. Paris: J.C. Lattès.

Cabot J. 1964. Le bassin du moyen Logone. PhD dissertation, Faculté des lettres et sciences humaines de l'Université de Paris.

Cabot J. 1967. Les lits du Logone. Paris: Sedes.

CBLT. 2008a. Analyse diagnostique transfrontalière du bassin du lac Tchad. Ndjaména: Programme CBLTFEM relatif à l'inversion de la tendance à la dégradation des ressources en terres et en eau.

CBLT. 2008b. Programme d'action stratégique pour le bassin du lac Tchad. Inversion des tendances à la dégradation des terres et des eaux dans l'écosystème du bassin du lac Tchad, version du PAS adopted 11 June 2008, projet GEF, BM UNDP, UNOPS.

CBLT, 2011. Collections of decisions of the LCBC Heads of State and Government Summits, Vol. 1: 19642010. N'Djaména: LCBC.

CBLT. 2012a. Rapport de l'atelier de validation du projet de rapport final de l'étude de faisablité du projet de transfert d'eau de l'Oubangui au lac Tchad. Niamey, 6-8 February. CBLT.

CBLT. 2012b. Charte de l'Eau du Bassin du lac Tchad. N'Djaména: CBLT.

Chandler L. 2001. Africa's Lake Chad shrinking by 20 times due to irrigation demands, climate change. note 1-17, Goddard Space Flight Center. 27 February. Greenbelt, MD: NASA. .

Cima International. 2011a. Etude de faisabilité du projet de transfert d'eau de l'Oubangui au lac Tchad, Document-synthèse: principaux résultats de l'étude de faisabilité. Laval, N'Djaména: Cimainternational, CBLT.

Cima International, 2011b. Etude de faisabilité du projet de transfert d'eau de l'Oubangui au lac Tchad. Projet de rapport final. Rapport principal. Laval, N'Djaména: Cima-international, CBLT.

Coe M.T., Foley J.A., 2001. Human and natural impacts on the water resources of the Lake Chad basin. Journal of Geophysical. Research (D) 106: 3349-3356.

Don-Donné Goudoum P. and J. Lemoalle, 2014. La crue du lac Tchad en 2013 vue par le satellite Landsat 8. N'Djaména. Revue scientifique du Tchad 1(4): 40-44.

Dresch J. 1947. A propos de la capture du Logone par la Bénoué. BAGF 188-189: 100-105.

Dubost G. 1998. Le colonel Roudaire et son projet de mer saharienne. Guéret: Société des sciences naturelles et archéologiques de la Creuse.

Fairhead, J. and M. Leach (eds.). 1998. Reframing deforestation: global analyses and local realities. Studies in West Africa. London: Routledge.

FAO, 2009. Lac Tchad ou la catastrophe humanitaire. L'assèchement du lac menace les moyens d'existence des riverains. Rome: FAO. 14 Oct. 2009, consulted $11^{\text {th }}$ May 2014. http://www.fao.org/news/story/fr/item/36171/icode

Gautier D. and T.A. Benjaminsen (eds.). 2012. Environnement, discours et pouvoir. L'approche Political ecology. Paris: Quae.

Hansen C.P., Lund J.F. and T. Treue. 2009. Neither fast, nor easy: the prospect of Reducing Emissions from Deforestation and Degradation (REDD) in Ghana. International Forestry Review 11(4): 439-454.

Kindler J., Warshall P., Arnould E.J., Hutchinson C.F. and R. Varady, 1990. Le bassin conventionnel du lac Tchad: une étude diagnostic de la dégradation de l'environnement. N'Djaména: CBLT, UNEP, UNDP.

Krings M. 2004. Fishing for naira: some social trends in Lake Chad fishery. An overview. In Krings M. and E. Platte (eds.). Living with the Lake. Köln: Rüdiger Köppe Verlag. Pp. 204-226.

Krings M. and E. Platte (eds.). 2004. Living with the Lake. Köln: Rüdiger Köppe Verlag.

Ladel J. 2007. Gestion intégrée des ressources en eau du bassin transfrontalier du lac Tchad. Final report, September. N'Djaména: CBLT, European Union. 
Leblanc M., Leduc C., Stagnitti F., van Oevelen P.J., Jones C., Mofor L.A., Razack M. and G. Favreau. 2006. Evidence for Megalake Chad, north-central Africa, during the late Quaternary from satellite data. Paleogeography, Paleoclimatology, Paleoecology 230: 230-242.

Lemoalle J. 2003. Lake Chad: a changing environment. In Nihoul J.C.J., Zavialov P.O. and P.P. Micklin (eds.) Dying and dead seas. Dordrecht: Kluwer. Pp. 321-340.

Lemoalle J. 2015. Les différents états du lac Tchad: un perpétuel changement. In Magrin G., Lemoalle J. and R. Pourtier (eds.). Atlas du lac Tchad. Paris: Passages, République du Tchad, AFD, CBLT, IRD.

Lemoalle J., Bader J.C. and M. Leblanc. 2011. Lake Chad. In Bengtsson, L., R. Herschy, R.W. Fairbridge and W. Rhodes (eds.). Encyclopedia of lakes. Dordrecht: Springer.

Lemoalle J., Bader J.C., Leblanc M. and A. Sedick. 2012. Recent changes in Lake Chad: observations, simulations and management options (1973-2011). Global and Planetary Change 80-81: 247-254.

Lemoalle J. and G. Magrin (eds.). 2014. Le développement du lac Tchad: situation actuelle et futurs possibles. Expert report and contributions. N'Djaména, Marseille: Expertise collégiale IRD, CBLT, AFD-FFEM.

Létolle R. and H. Bendjoudi. 1997. Histoires d'une mer au Sahara: utopies et politiques. Paris: L'Harmattan, Paris.

Luxereau A., Genthon P. and A. Karimou. 2011. Fluctuations in the size of Lake Chad: consequences on the livelihoods of the riverain peoples in eastern Niger. Regional Environmental Change 12(3): 507-521..

Magrin G., 1996. Crise climatique et mutations de l'agriculture: l'émergence d'un grenier céréalier entre Tchad et Chari. Annales de géographie 592: 620-644.

Magrin G. 2007. Le lac Tchad n'est pas la mer d'Aral. Mouvements November. http://www.mouvements.info/spip.php?article201

Magrin G., 2009. De longs fleuves tranquilles? Les mutations des plaines refuges du bassin tchadien. In Raison J.P. and G. Magrin (eds.). Des fleuves entre conflits et compromis. Essais d'hydropolitique africaine. Paris: Karthala. Pp. 125-172.

Magrin G. 2010. En attendant le centenaire... Introduction au dossier Afrique, 50 ans d'indépendance. Territoires, frontières, identités et développement. EchoGéo 13.

Magrin G. 2011. Sauver le lac Tchad autrement. Sur la piste du développement durable dans le bassin tchadien. Passages 166: 18-22.

Magrin G. 2013. Voyage en Afrique rentière. Une lecture géographique des trajectoires du développement. Paris: Publications de la Sorbonne.

Magrin G. 2014. Les défis pour le lac Tchad de la gouvernance des ressources en eau à l'échelle du bassin. In Lemoalle J. and G. Magrin (eds.) Le développement du lac Tchad: situation actuelle et futurs possibles. Expert report and contributions. N'Djaména, Marseille: Expertise collégiale IRD, CBLT, AFD-FFEM.

Magrin G. and G. Maoundonodji. 2012. Le projet Rônier pour la Chine et pour le Tchad. Enjeux d'une nouvelle aventure pétrolière. In van Vliet G. and G. Magrin (eds.). Une compagnie pétrolière chinoise face à l'enjeu environnemental au Tchad. Paris: AFD. Pp. 121-149.

Magrin G., Lemoalle J. and C. Raimond. 2014. Les futurs du lac Tchad: réflexions prospectives, en guise de conclusion. In Lemoalle J. and G. Magrin (eds.). Le développement du lac Tchad : situation actuelle et futurs possibles. Expert report and contributions. N'Djaména, Marseille: Expertise collégiale IRD, CBLT, AFD-FFEM.

Magrin G., Réounodji F., Ngaressem G., Mbagogo A., Assouyouti M., 2010. Le lac Tchad et N'Ndjaména: une relation porteuse de développement? Communication au colloque PRASAC-ARDESAC « Savanes africaines en développement. Innover pour durer », Garoua, 20-24 avril 2009. Published on CD Rom. http://hal.cirad.fr/cirad-00471340/fr/ 
Magrin G., and J. Lemoalle. 2015. Les projets de transfert d'eau vers le lac Tchad: des utopies initiales aux défis contemporains. In Magrin G., R. Pourtier and J. Lemoalle (eds.). Atlas du lac Tchad. Paris: Passages, République du Tchad. AFD, IRD. Pp. 156-158.

Maley J., 1981. Etudes palynologiques dans le bassin du lac Tchad et Paléoclimatologie de l'Afrique Nord Tropicale, de 30,000 ans à l'époque actuelle. Thèse Sciences, nº 129 . Travaux et documents de l'ORSTOM.

Marçot J.L. 2003. Une mer au Sahara. Paris: La Différence.

Mbagogo A.K. and G. Magrin, 2015. L'agriculture de décrue: innovations et contraintes. In Magrin G., Lemoalle J. and R. Pourtier (eds.). Atlas du lac Tchad. Paris: Passages. République du Tchad, AFD, IRD.

Ngaressem G.M., Magrin G., Waziri M., Mbagogo A.K. and M. Abdourahamani. 2014. La population du lac Tchad d'après les recensements: densification et attraction différenciée. In Lemoalle J. and G. Magrin (eds.). Le développement du lac Tchad: situation actuelle et futurs possibles. Expert report and contributions. N'Djaména, Marseille: Expertise collégiale IRD, CBLT, AFD-FFEM.

Olivry J.C., Chouret A., Vuillaume G., Lemoalle J. and J.P. Bricquet. 1996. Hydrologie du lac Tchad. Paris: ORSTOM.

Peet R., Robbins P. and M.J. Watts (eds.). 2011. Global political ecology. Routledge.

Pegg S. 2009. Chronicle of a death foretold: the collapse of the Chad-Cameroon Pipeline Project. African Affairs 108/432: 311-320.

Pelletier, P. 1993. L'imposture écologiste. Montpellier: Reclus.

Pouyaud B. and J.Colombani. 1989. Les variations extrêmes du lac Tchad: l'assèchement est-il possible? Annales de géographie 545: 1-23.

Raimond C., Rangé C. and H. Guérin. 2014. La multi-activité et la multi-fonctionnalité, principes d'un fonctionnement durable pour le Lac? In Lemoalle J. and G. Magrin (eds.). Le développement du lac Tchad : situation actuelle et futurs possibles. Expert report and contributions. N'Djaména, Marseille: Expertise collégiale IRD, CBLT, AFD-FFEM.

Raison J.P. and G. Magrin (eds.). 2009. Des fleuves entre conflits et compromis: essais d'hydropolitique africaine. Paris: Karthala.

Redon M., Magrin G., Chauvin E., Perrier-Bruslé L. and E.Lavie (eds.). 2015. Ressources mondialisées: essais de géographie politique. Paris: Publications de la Sorbonne.

Réounodji F. 1995. Conséquences de la sécheresse sur les activités humaines: les exemples de Karal et de Guitté au sud du lac Tchad. Revue scientifique du Tchad IV-1: 59-69.

Roehrig R., Bouniol D., Guichard F., Hourdin F. and J.L. Redelsperger. 2013. The present and future of the West African Monsoon: a process-oriented assessment of CMIP5 simulations along the AMMA transect. Journal of Climate 26: 6471-6505.

Rossi G. 2000. L'ingérence écologique. Environnement et développement rural du Nord au Sud. Paris: CNRS Editions.

Sarch M.T. and C. Birkett. 2000. Fishing and farming at Lake Chad: responses to lake-level fluctuations. The Geographical Journal 166 (2): 156-172.

Sautter G. 1987. Libres réflexions sur les aménagements ayant pour objet la maîtrise de l'eau par ou pour les agriculteurs. Aménagement et Nature 111: 1-5.

Sörgel H. 1932. Atlantropa. Zürich, Münich: Fretz and Wasmuth, / Piloty and Loehle.

Tiffen, M., M.J. Mortimore and F. Gichuki. 1994. https://www.odi.org/sites/odi.org.uk/files/odiassets/publications-opinion-files/4600.pdf. Chichester: John Wiley

Tilho J. 1928. Variations et disparition possible du lac Tchad. Annales de géographie 37: 238-260.

Urvoy Y. 1949. Histoire de l'empire du Bornou. Paris: Larose. 
Veyret Y. and P. Arnould (eds.). 2008. Atlas des développements durables. Paris: Autrement.

Vuillaume G. 1981. Bilan hydrologique mensuel et modélisation sommaire du lac Tchad. Cahiers ORSTOM, série Hydrol. XVIII-1: 23-72.

Welcomme R.L. 1979. Fisheries ecology of floodplain rivers. London, New York: FAO. 